\title{
The features and aetiology of Fournier's gangrene
}

\author{
S.E.E. Efem \\ University Teaching Hospital, Calabar, Nigeria
}

Summary: This paper reports a clinical study of 20 cases of gangrenous ulcers of the scrotum and/or of the penis (Fournier's gangrene) and a review of previous publications. Even though found mostly in elderly male patients, the disease spares no age group and can involve the external genitalia in neonates and women as well. The disease is a necrotising fasciitis of infective origin and always has a portal of entry of the infecting organisms even though it may be so trivial as to be undetected. The commonest portals of entry of infection are periurethral sepsis, groin wound sepsis, anorectal sepsis, prostatic sepsis and trauma. The infecting organisms comprise both aerobic and anaerobic organisms such as Escherichia coli, Streptococcus pyogenes, Pseudomonas aeruginosa, Klebsiella pneumonia, Proteus mirabilis, enterococci, Bacteroides fragilis and anaerobic streptococcus. Fournier's gangrene is probably the same disease as necrotizing fasciitis occurring in other parts of the body, but modified by the peculiar anatomy of the genitoperineum.

\section{Introduction}

In 1843 and 1844 Alfred Jean Fournier described cases of scrotal gangrene in France. ${ }^{1,2} \mathrm{He}$ called the condition idiopathic scrotal gangrene since he could not determine the aetiology. Rather than searching diligently for the aetiology, clinicians have been content in also calling it idiopathic scrotal gangrene or Fournier's gangrene. ${ }^{3-5}$ Those who attempt to search for the aetiology are told that those for which the aetiology can be found are not Fournier's gangrene or simply that gangrenous conditions of the scrotum are not Fournier's gangrene.

This prospective study of 20 consecutive cases of Fournier's gangrene and literature review is aimed at resolving some of the controversy, and defining the features and aetiology of Fournier's gangrene.

\section{Patients and methods}

Twenty consecutive cases of gangrenous ulcers of the scrotum and/or of the penis (Fournier's gangrene) managed by the author from January 1983 to June 1991 are the subject of this prospective study. The patients' age and sex, and the site, extent and

Correspondence: Professor S.E.E. Efem, F.R.C.S., F.I.C.A., F.W.A.C.S., F.I.C.S., University Department of Surgery, Royal Free Hospital, Pond Street, London NW3 2QG, UK.

This paper was read at the 25th Biennial Congress of the International College of Surgeons in Cairo in November 1992.

Accepted: 28 February 1994 origin of the ulcers were sought and documented. The patients' social class, nutritional stą, associated illness and constitutional disturbane ${ }^{-}$ were also investigated. Foci of infection in their perineum and anorectal regions were sought. Blood was taken for fasting sugar, haemoglobin, white cell total and differential counts and from

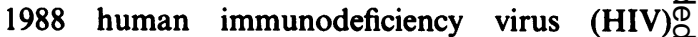
serological status was determined.

\section{Results}

A total of 20 cases was studied. The patients' ages 3 . ranged from one month to 80 years and all were males. The patients were all from the lowest socioeconomic group. They were either mal-o̊ nourished or had borderline nutritional status. Apart from one patient who had congestive cardiac응 failure, there was no evidence of systemic illnesses $>$ such as diabetes mellitus or chronic renal failure, and none had any major constitutional distur- $N$ bance. Those tested for HIV antibodies were negative. Their haemoglobin concentrations ranged $N$ from 7-10 g/dl. White blood cell counts ranged $\mathrm{\omega}^{N}$ between 6 and $16 \times 10^{9} / 1$.

Sixteen cases had gangrene involving theo scrotum alone, two cases involved both the $\frac{\widetilde{D}}{\mathbb{D}}$ scrotum and the penis, while two cases involved the $\stackrel{?}{+}$ penis alone. The aetiological factors elicited were -0 groin wound sepsis in eight cases $(40 \%)$, lower

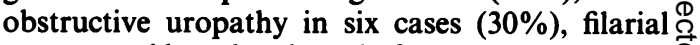
penoscrotal lymphoedema in four cases $(20 \%)$ and $\stackrel{\mathbb{Q}}{\Omega}$ trauma in two cases $(10 \%)$ (Table I). 
Table I The aetiology of 20 cases of Fournier's gangrene in Calabar

\begin{tabular}{lc}
\hline Aetiology & No. of cases \\
\hline $\begin{array}{l}\text { Lower obstructive uropathy } \\
\text { Urethral stricture }\end{array}$ & 3 \\
$\begin{array}{l}\text { Urethral stricture + watering can } \\
\text { scrotum }\end{array}$ & 2 \\
$\quad$ Traumatic urethral catheterisation & 1 \\
$\begin{array}{l}\text { Groin wound sepsis } \\
\text { Strangulated inguinoscrotal hernia } \\
\text { Strangulated Richter's hernia + } \\
\text { faecal fistula }\end{array}$ & 4 \\
$\quad \begin{array}{l}\text { Infected suprapubic cystostomy } \\
\text { Filarial penoscrotal lymphoedema } \\
\text { Onchocerciasis } \\
\text { ? Bancroftian }\end{array}$ & 1 \\
$\begin{array}{l}\text { Trauma } \\
\text { Scratching of the scrotum } \\
\quad \text { congestive cardiac failure) }\end{array}$ & 3 \\
$\quad \begin{array}{l}\text { Corrugated-rubber drain applied to } \\
\text { scrotum }\end{array}$ & 1 \\
\hline
\end{tabular}

The organisms cultured were Escherichia coli, Klebsiella pneumonia, Pseudomonas aeruginosa, Proteus mirabilis, enterococci, Streptococcus pyogenes and Staphylococcus aureus. Some organisms were cultured from more than one patient while some patients grew a mixture of organisms. Only in a few instances were single organisms cultured.

\section{Discussion}

Fournier's gangrene and necrotizing fasciitis are one and the same disease. Whereas Fournier in 1843 and 1844 described it as idiopathic and in relation to the scrotum, many authors described the disease with various other names and in relation to various parts of the body..$^{5-27}$ Hence Meleney in 1924 described it in relation to haemolytic streptococcus $^{28,29}$ and Cullen in 1924 also described it in relation to bacteria acting in synergism on postoperative abdominal wound infection. ${ }^{29}$ It was not until 1952 that Wilson eventually introduced the term necrotizing fasciitis ${ }^{30}$ that the true nature of this disease became apparent. It is an infective gangrene which involves the subcutaneous fascia and part of the deep fascia and may involve any part of the body, even though it tends to have a predilection for the genitoperineum, lower abdominal wall and upper thigh. Various organisms are involved and these depend on the patient and the part of the world. Both aerobic and anaerobic organisms are involved and tend to act in synergism. ${ }^{18}$

At the outset there is pain, oedema and redness of the skin, and later dusky discoloration and then
Table II The aetiology of Fournier's gangrene

\begin{tabular}{|c|c|}
\hline Idiopathic & Reference \\
\hline Undetermined origin & $\begin{array}{l}\text { Fournier }{ }^{1,2} \\
\text { Mair }^{3} \\
\text { Thomas }^{4,5}\end{array}$ \\
\hline \multicolumn{2}{|l|}{ Infection } \\
\hline $\begin{array}{l}\text { Urethral and perianal } \\
\text { sepsis }\end{array}$ & Fahal $^{6}$, Wholach 7 \\
\hline Urogenital sepsis & Octavio $^{8}$ \\
\hline Anorectal sepsis & Hirn 9 \\
\hline Intersphincteric abscess & Jaimieson $^{10}$ \\
\hline Prostatic massage & Sengoku"11 \\
\hline $\begin{array}{l}\text { Gram-negative synergistic } \\
\text { organisms }\end{array}$ & Leenen $^{12}$ \\
\hline Pyoderma gangrenosum & Baskin $^{13}$ \\
\hline Perirectal abscess & Lamb $^{14}$ \\
\hline \multicolumn{2}{|c|}{ Mechanical lower obstructive uropathy } \\
\hline $\begin{array}{l}\text { Advanced periurethral } \\
\text { extravasation }\end{array}$ & Gray ${ }^{15}$ \\
\hline Urethral stricture & Bahlmann ${ }^{16}$ \\
\hline Urethral calculus & Walker ${ }^{17}$ \\
\hline Urethral lithiasis & Campos $^{18}$ \\
\hline \multicolumn{2}{|l|}{ Trauma } \\
\hline Scrotal trauma & Hirn? \\
\hline Male sterilization & Pryor ${ }^{19}$ \\
\hline $\begin{array}{l}\text { Traumatic urethral } \\
\text { catheterization }\end{array}$ & $\mathrm{Conn}^{20}$ \\
\hline \multicolumn{2}{|l|}{ Vascular pathology } \\
\hline Hypersensitivity vasculitis & Sohn ${ }^{21}$ \\
\hline $\begin{array}{l}\text { Thrombosis of penile } \\
\text { vessels }\end{array}$ & Campos $^{18}$ \\
\hline Thrombosis & Edington $^{22}$ \\
\hline Arteritis nodosa & $\mathrm{Efem}^{23}$ \\
\hline \multicolumn{2}{|l|}{ Metabolic disorders } \\
\hline Diabetes mellitus & Lok $^{24}$, Aasen $^{25}$, Octavio $^{8}$ \\
\hline Alcohol abuse & Aasen, ${ }^{25}$ Wolach $^{7}$ \\
\hline \multicolumn{2}{|l|}{ Lymphatic obstruction } \\
\hline Filarial lymphoedema & Edington $^{22}$, Davey $^{25}$ \\
\hline Strangulated groin hernia & \\
\hline $\begin{array}{l}\text { Strangulated Richter's } \\
\text { hernia }\end{array}$ & Efem $^{23}$ \\
\hline
\end{tabular}

blistering before ulceration. Even before ulceration there is subcutaneous necrosis and severe toxaemia requiring aggressive antibiotic therapy, incision, drainage and debridement. On account of lack of subcutaneous fat in the scrotum, necrosis of fascia containing the Dartos leads of exposure of the testis which may be coated with a thick layer of creamy pus. The testes are usually spared by the fact that the blood supply is intact, being derived from the abdominal aorta at the level of the second lumbar vertebra. The muscle layer of the penis is also usually spared, thus the skin sloughs off leaving the muscles. However, Campos et al. ${ }^{18}$ described a case of Fournier's gangrene following synchronous cavenospongious thrombosis secondary to urethral lithiasis.

The disease is common in the older age group 
and uncommon in children and adolescents. It has, however, been described in neonates and infants. ${ }^{31,32}$ Even though rare it occurs in females and it usually involves the labia majora. ${ }^{33}$

Fournier's gangrene is primarily an infective condition and has several predisposing comorbid and aetiological factors, and several portals of entry of the infecting organisms. These organisms include Staphylococcus aureus, Klebsiella pneumonia, Pseudomonas aeruginosa, Proteus mirabilis, enterococci, Bacteroides fragilis, anaerobic streptococcus and others. ${ }^{67,18}$ These are identical to the organisms isolated in this study. The usual predisposing aetiological factors are diabetes mellitus, alcohol overindulgence, thrombosis, urethral obstruction and various causes ${ }^{22,23}$ of perineal sepsis (Table II). The usual portals of entry include urethral sepsis, genital sepsis, prostatic sepsis, perianal sepsis, ischiorectal abscesses, trauma, groin wound sepsis, etc. ${ }^{6-18}$

The incident leading to the inoculation of organism that leads to this rapidly fatal condition may be so trivial that the patient or even the attending clinician fails to notice it. For example, scratching of the scrotum enlarged and stretched by onchocerciasis may inoculate organisms into the skin which leads to cellulitis which progresses to

\section{References}

1. Fournier, J.A. Gangrene foudroyante de loa verge. Med Pract Paris 1883, 4: 589-597.

2. Fournier, J.A. Etude clinique de la gangrene foudroyante de la verge. Semaine Med 1884, 4: 69-74.

3. Mair, G.B. Idiopathic gangrene of the scrotum. Lancet 1945 , 1: 464.

4. Thomas, H.O. Idiopathic gangrene of the scrotum in West Africans. Br J Surg 1953, 25: 60-62.

5. Thomas, J.F. Fournier's gangrene of the penis and scrotum. $J$ Urol 1956, 75: 719-727.

6. Fahal, A.H. \& Hassan, M.A. Fournier's gangrene in Khartoum, Sudan. Br J Urol 1988, 61: 451-454.

7. Wolach, M.D., MacDermott, J.P., Stone, A.R. \& de Vere White, R.W. Treatment and complications of Fournier's gangrene. Br J Urol 1989, 64: 310-314.

8. Octavio-Castillo, C. \& Carlos-Martinez, S. Flemon perineal necrotizante (Gangrene de Fournier). Necrotising perineal phlegmon (Fournier's gangrene). Acta Urol Esp 1989, 13: $381-383$.

9. Hirn, M. \& Niinikoski, J. Management of perineal necrotising fasciitis (Fournier's gangrene). Ann Chir Gynaecol 1989, 78: $277-281$.

10. Jamieson, N.V., Everett, W.G. \& Bullock, K.N. Delayed recognition of an intersphincteric abscess as a cause of Fournier's scrotal gangrene. Ann Roy Coll Surg Engl 1984, 66: 434-435.

11. Sengoku, A., Yamashita, M. \& Umezu, K. A case of Fournier's gangrene: was it triggered by prostatic massage? Hinyokika Kivo 1990, 36: 1097-1100 (in Japanese).

12. Leenen, L.P. \& Van de Werken, C. Gangrene van Fournier (Fournier's gangrene). Acta Chir Belg 1990, 90: 204-206.

13. Baskin, I.S., Doxon, C., Stoller, M.L. \& Carroll, P.R. Pyoderma gangrenosum presenting as Fournier's gangrene. $J$ Urol 1990, 144: 984-986.
Fournier's gangrene. Other examples of causes are urethral catheterization, ${ }^{20}$ prostatic massage ${ }^{21}$ and vasectomy. ${ }^{19}$

Similarly, Lamb and Juler in California were $\stackrel{\varrho}{\complement}$

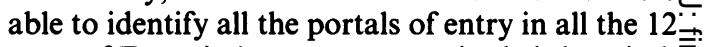
cases of Fournier's gangrene seen in their hospital: in five cases infection orginated from perirectalo infection, four from surgical procedures and three음 from urethral sepsis. ${ }^{14}$ Again, Asfar et al. in their $\overline{\bar{c}}$. description of 16 cases of necrotizing fasciitis, eight $\widehat{ }_{\propto}$ of which were Fournier's gangrene, identified allo the predisposing comorbid and aetiological fac-s tors, namely, diabetes mellitus (six cases), perianal. abscess (three cases), chronic renal failure (three $\vec{\omega}$ cases), balanitis, perforated adenocarcinoma of the sigmoid colon and ischaemia of both legs (one case each). ${ }^{34}$

In conclusion, Fournier's gangrene is a necrotising fasciitis of the genito-perineum of infective origin and is essentially the same disease as nec-N rotising fasciitis in any other part of the body, itser peculiarity being determined by the anatomy of the region. It is never idiopathic. When the aetiology is not found, it only means that the clinician is unableto determine the aetiology by virtue of the fact that? the portal of entry may have been so trivial as to be을 overlooked.

14. Lamb, R.C \& Juler, G.L. Fournier's gangrene of the scrotum. A poorly defined syndrome or a misnomer? Arch Surg 1983, 118: 38-40.

15. Gray, J.A. Gangrene of the genitalia in advanced periurethral ${ }_{\stackrel{D}{Q}}$ extravasation with phlegmon. J Urol 1960, 84: 740-745.

16. Balhamann, J.C.M., Fourie, J.V.H. \& Arndt, T.C.M. Four-음 nier's gangrene: necrotising fascitis of the male genitalia. $\mathrm{Br} J$ Urol, 1983, 55: 85-88.

17. Walker, L., Cassidy, M.T., Hutchinson, A.G., Abel, B.J. \& Lewis, H.J.E. Fournier's gangrene and urethral problems. $\mathrm{Br}$ J Urol 1984, 56: 509-511.

18. Campos, J.A., Martos, J.A., Gutierez del Pozo, R. \& Carretero, P. Synchronous caverno-spongious thrombosis $\bar{\sigma}$ and Fournier's gangrene. Arch Esp Urol 1990, 43: 423-426그.

19. Pryor, J.R., Bella, J.Y. \& Packham, D.A. Scrotal gangrene? after male sterilization. Br Med J 1971, 1: 272.

20. Conn, I.G. \& Lewis, H.J.E. Fournier's gangrene of the scrotum following traumatic urethral catheterization. $J$ Roy음 Coll Surg 1987, 32: 182-184.

21. Sohn, M., Kistler, D., Kindler, J. \& Lutzeyer, W. Fournier'so gangrene in hypersensitivity vasculitis. J Urol 1989, 142:三. 823-825.

22. Edington, G.M. \& Giles, H.M. Fournier's gangrene. In: Edington, G.M. \& Giles, H.M. (eds) Pathology in the Tropics, $N$ 2nd edn. Edward Arnold, London, 1976, pp. 553-555.

23. Efem, S.E.E. Strangulated Richter's hernier presenting as $\omega$ Fournier's gangrene. Postgrad Doctor Africa 1985, 7응 $181-182$.

24. Lok, C., Trabettoni, M., Labeille, B. et al. Fasciite necrosante $\frac{c}{\Phi}$ synergistique du perinee gangrene de Fournier. Ann Dermatol Venerol 1989, 116: 846-847. 
25. Aasen, A.O., Rund, T.H., Haffne, J., Raeder, M. et al. Kirurgisk behandling ved nekrostiserende fascitis (surgical treatment of necrotising fascitis). Tidsskr Norway Laegeforen 1989, 109: 2768-2772.

26. Davey, W.W. Fournier's gangrene. In: Davey, W.W. (ed) Companion to Surgery in Africa. Churchill-Livingstone, Edinburgh, 1968. pp 396-398.

27. Lee, O.G.C. Necrotising fascitis of genitalia. Urology 1979, 13: 604-606.

28. Meleney, F.L. Haemolytic streptococcal gangrene. Arch Surg 1924, 9: 317-364.

29. Cullen, T.S. A progressive enlarging ulcer of abdominal wall involving the skin and fat, following drainage of abdominal abscess apparently of appendiceal origin. Surg Gynecol Obstet 1924, 38: 579-582.
30. Wilson, B. Necrotising fascitis. Am J Surg 1953, 18: 416-431.

31. Adams, J.R., Jr, Mata, J.A., Venable, D.D., Culkin, D.J. \& Bocchini, J.A., Jr. Fournier's gangrene in children. Urology 1990, 35: 439-441.

32. Silva-Villasenor, J.A., Velazquez Macias, R.F., Suarez, J.J., Galvan Mantano, A. \& Quintos Aranda, C. Fournier's gangrene in a newborn. Bol Med Hosp Infant Mex 1990, 47: 48-50.

33. Bugra, D., Bozfakioglu, Y., Buyukuncu, Y. \& Bulut, T. Gangrene de Fournier: etude analytique de six cas (Fournier's gangrene: analytical study of 6 cases). J Chir Paris 1990, 127: $115-116$.

34. Asfar, S.K, Baraka, A., Juma, T., Ma'Rafie, Q., Aladeen, T. \& Al Sayer, H. Necrotising fascitis. Br J Surg 1991, 78: 838-840. 